\title{
Translation and Brazilian adaptation of the Relationship Scales Questionnaire (RSQ)
}

\author{
Tradução e adaptação brasileira do Relationship Scales Questionnaire (RSQ)
}

\author{
Eunice Neves de Assis, ${ }^{1}$ (D) Fernanda Soares Loureiro, ${ }^{1}$ Caroline Menta, ${ }^{1}$ Eduardo Lopes Nogueira, ${ }^{2}$ \\ Irênio Gomes da Silva Filho, ${ }^{1}$ Armin von Gunten, ${ }^{3}$ Alfredo Cataldo Neto ${ }^{1}$
}

\begin{abstract}
Objectives: To describe the process of translating and adapting the Relationship Scales Questionnaire (RSQ) from English into Brazilian Portuguese and to present the results of its test-retest reliability using the version developed for interview application. Methodology: The process was based on the guidelines of the International Society for Pharmaeconomics and Outcomes Research (ISPOR), which propose 10 steps for the translation and cross-cultural adaptation of self-administered instruments. The original authors of the RSQ have agreed to the translation. The interview version was applied to a sample of 43 healthy elders ( $\geq 60$ years old) enrolled in a primary health care program in the city of Porto Alegre, state of Rio Grande do Sul, southern Brazil, and then reapplied. The scores of the two applications were compared using the paired sample t-test.

Results: Only 6 of the 30 items required the adaptation of words or expressions to maintain its conceptual and semantic equivalence. The self-administered form of the RSQ posed difficulties for elders due to visual deficiencies and lower education level, both common in this age group, demonstrating a need for the development of a version of the RSQ in a structured interview format. Only the measure for secure attachment presented significant differences after the application of the retest, indicating reliability of the version being proposed.

Conclusion: Translation of the RSQ is the first step towards the validation of an attachment evaluation instrument for use in the elderly population in Brazil, allowing for future studies on this topic.
\end{abstract}

Keywords: Relationship Scales Questionnaire, translation, object attachment, aging.

\section{Resumo}

Objetivos: Descrever o processo de tradução e adaptação cultural do questionário Relationship Scales Questionnaire (RSQ) do inglês para o português do Brasil e apresentar os resultados de confiabilidade teste-reteste utilizando a versão desenvolvida para aplicação em entrevista.

Metodologia: O método utilizado teve como diretriz a proposta da International Society for Pharmaeconomics and Outcomes Research (ISPOR), de 10 passos para a tradução e adaptação transcultural de instrumentos autoaplicáveis. Os autores originais do RSQ concordaram com a tradução. A versão para entrevista dirigida foi aplicada em uma amostra de 43 idosos saudáveis ( $\geq 60$ anos) cadastrados em um programa de atenção primária à saúde na cidade de Porto Alegre, RS, sendo então reaplicada. As pontuações das duas aplicações foram comparadas usando o teste $t$ de Student para amostras pareadas.

Resultados: Apenas 6 dos 30 itens precisaram de adaptação cultural de palavras ou expressões para manter sua equivalência conceitual e semântica. O formato autoaplicável do RSQ mostrou-se pouco adequado entre idosos, devido à presença comum de déficits visuais e baixa escolaridade, demonstrando a necessidade do desenvolvimento de uma versão do RSQ em formato de entrevista dirigida. Apenas a medida de apego seguro apresentou diferença significativa após a aplicação do reteste, indicando a confiabilidade da versão proposta.

Conclusão: A tradução do RSQ é o primeiro passo para a validação de um instrumento de avaliação de apego para a população idosa no Brasil, permitindo futuros estudos sobre o tema.

Descritores: Relationship Scales Questionnaire, tradução, apego ao objeto, envelhecimento.

\footnotetext{
1 Programa de Pós-Graduação em Gerontologia Biomédica, Escola de Medicina, Pontifícia Universidade Católica do Rio Grande do Sul (PUCRS), Porto Alegre, RS, Brazil. ${ }^{2}$ Hospital São Lucas (HSL), PUCRS, Porto Alegre, RS, Brazil. ${ }^{3}$ Service Universitaire de Psychiatrie de l'âge Avancé (SUPAA), Centre Hospitalier Universitaire Vaudois (CHUV), Lausanne, Switzerland.

This article was extracted from the first author's Master's dissertation entitled "Tradução e adaptação transcultural da escala de apego Relationship Scales Questionnaire (RSQ) para o português brasileiro," presented in March 2018 at Programa de Pós-Graduação em Gerontologia Biomédica, Pontifícia Universidade Católica do Rio Grande do Sul (PUCRS), Porto Alegre, RS, Brazil.

Submitted May 17 2018, accepted for publication Jul 202018.

Suggested citation: de Assis EN, Loureiro FS, Menta C, Nogueira EL, da Silva Filho IG, von Gunten A, et al. Translation and Brazilian adaptation of the Relationship Scales Questionnaire (RSQ). Trends Psychiatry Psychother. 2019;41(1):69-77. http://dx.doi.org/10.1590/2237-6089-2018-0032
} 


\section{Introduction}

During the past century, the increase in life expectancy in the majority of countries has turned population aging into a worldwide phenomenon, and it occurs at an even more accelerated pace in developing countries like Brazil. ${ }^{1}$ This demographic change will impact health services with an increased demand for treatment of chronic degenerative non-communicable diseases. Dementias are among the most common of such diseases, and are potentially onerous to health systems ${ }^{2}$ and stand out for their prevalence of comorbidity, high risk for incapacitation, and increase in high-cost and long-term care. ${ }^{3}$

Despite advances in the understanding of the neurobiological processes involved in the pathological course of dementias, the complexity of these diseases makes it clear that there is still a lot to be learned in terms of risk group identification, early diagnosis, and better management of behavioral and psychological symptoms of dementia, which serve as a large cause of stress and suffering for the patients as well as their families and caretakers.

Attachment is one of the psychosocial factors associated with dementias, and few studies have been conducted on the topic by the scientific community. As a result, there are great possibilities for intervention. Bowlby defines attachment as the behavior of seeking and maintaining proximity to another individual, emphasizing its contribution to the formation and maintenance of human species social groupings. ${ }^{4}$ This essentially systemic understanding perceives the individual in continuous and reciprocal attachment behavior during life through more or less stable relationship patterns among individuals. ${ }^{5}$ These patterns are especially responsible for the feelings of support and safety, and therefore can play a crucial role in dealing with stressful situations caused by the physiological, functional and cognitive alterations characteristic of dementia.

There are two main theoretical lines in the study of adult patterns of attachment: the three-category model and the four-category model. The three-category model is based on the classic studies by Ainsworth on childhood patterns of attachment, ${ }^{6}$ dividing the pattern of attachment into three types: safe, avoiding, and anxious/ambivalent. Hazan \& Shaver, ${ }^{7}$ who are among the main authors of the three-group system, translated the descriptions of the patterns identified by Ainsworth using terms appropriate to an adult context and found such patterns in adult populations.

Meanwhile, the four-category model is based on a two-dimensional model of adult attachment, where the patterns of attachment are divided into four types: safe, worried, fearful, and avoiding. This model, proposed by Bartholomew and collaborators, ${ }^{8-10}$ is based on theoretical propositions by Bowlby, in which the relationship of children with their caretakers leads to the formation of internal representations, both of the self and of others, that later guide social relations. In addition to describing the patterns of attachment in a more detailed manner, the four-category model can offer more personalized analyses, allowing for the possibility of changes in the patterns exhibited by an individual depending on instances of social relation.

Despite theoretical progress, attachment in adults is a recent area of research, with the majority of studies having been conducted with young adults. However, studies with the elderly have shown interesting results that can contribute to a better understanding of the cognitive and behavioral symptoms related to degenerative brain diseases.

In a Dutch study, Miesen investigated the connection between attachment behaviors in relation to family members, parental fixation (understood as the belief that long-deceased parents are still alive), and level of cognitive impairment in patients with Alzheimer's disease. The results showed that the stronger the cognitive impairment, the lower the attachment behavior in relation to current family members, and the higher the parental fixation manifested. Miesen theorized that the cognitive impairments associated with Alzheimer's disease complicate interactions with the environment, turning it into a constant source of stress and leading the elder to seek the proximity of family members (attachment behavior) as a way of feeling safe. Disease progression and the incapacity to recognize family members make the individual turn to older objects of attachment (parents), with parental fixation then becoming the attachment behavior itself, according to Miesen. ${ }^{11}$ In an attempt to recreate Miesen's study, Browne \& Shlosberg found an association between the pre-morbid pattern of attachment and the manifestation of attachment behaviors (for example, following caretakers or calling for them when they are out of view), with the participants classified with an avoiding pattern of attachment manifesting these behaviors more than those classified as safe. ${ }^{12}$

Another study related the pre-morbid pattern of attachment to behavioral and psychological symptoms of dementia in individuals with dementia. ${ }^{13}$ The authors observed that individuals with an avoiding attachment pattern presented more paranoid delusions, while those classified with an ambivalent pattern exhibited more anxiety and anguish. The insecure attachment type was associated with a higher level of overburdening their caretakers. 
Recently, a therapeutic approach using dolls has been employed to manage the behavioral and psychological symptoms of dementia in elders, based on the principles of attachment theory. The technique has shown to be effective in relieving emotional and behavioral symptoms, offering an increased sense of well-being and better interactions between elders with dementia and their external environment. Despite its promising results, the technique may not be effective on all patients, ${ }^{14}$ requiring more studies on the individual characteristics of the patients subjected to this therapeutic treatment, among them the patterns of attachment.

There are some important tools for the study of attachment using psychological evaluation instruments and techniques. In Brazil, however, there is no validated instrument for the evaluation of attachment in elders, which hinders the advancement of studies in this area for this population.

Considering this context, the choice of crossculturally adapting an instrument already used and recognized in a variety of foreign studies offers the possibility of reproducing studies and comparing results between population samples from different countries. In this sense, the Relationship Scales Questionnaire (RSQ), developed by Griffin \& Bartholomew ${ }^{10}$ based on three previous scales of attachment, presents itself as an option to evaluate attachment.

The objective of this work was to present the process of translation and cross-cultural adaptation of the RSQ into Brazilian Portuguese and the results of its test-retest reliability obtained by applying a version of the RSQ in Brazilian Portuguese developed for interview application.

\section{Methodology}

The RSQ presents 30 declarative statements that express feelings and thoughts related to close relationships with people. Each of the statements must be answered according to a Likert scale ranging from 1 to 5 , where 1 ("nothing like me" in the original) represents total disagreement with the statement and 5 represents total agreement ("totally like me"); answers 2 to 4 correspond to partial agreement ("somewhat like me").

The translation of the RSQ was based on the principles laid out by the Task Force for Translation and Cultural Adaptation of the International Society for Pharmaeconomics and Outcomes Research (ISPOR). ${ }^{15}$ These principles are the result of a revision of 12 of the main guidelines for translation and cultural adaptation and propose a 10-step process, which served as guidelines for the entire translation process (Figure 1).

The preparation phase began by contacting the authors of the original RSQ, who agreed to the development of the Brazilian version of the scale. Still during this stage, the professionals able to develop the

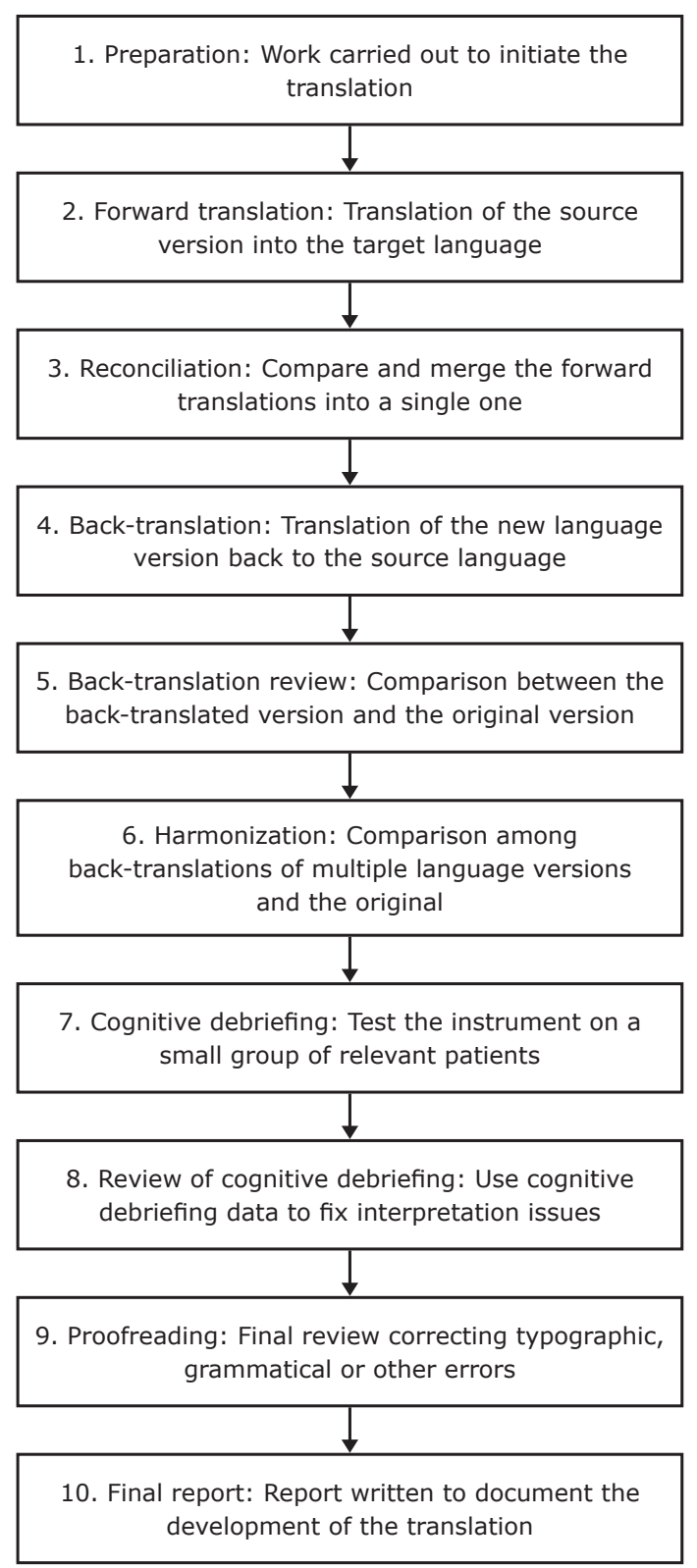

Figure 1 - Flowchart of the translation stages of the Relationship Scales Questionnaire (RSQ) into Brazilian Portuguese based on the principles for translation and cross-cultural adaptation of the International Society for Pharmaeconomics and Outcomes Research (ISPOR). ${ }^{11}$ 
necessary tasks for the upcoming stages were selected and consulted about their availability for the project.

In the second phase, two translations were made, conducted independently from one another by two researchers, both health professionals with experience in using psychological instruments, residents of Brazil, and fluent in English. The researchers also participated in the reconciliation phase, together with project coordinators, in order to develop the first version of the scale in Brazilian Portuguese, produced based on the two translations resulting from the prior phase.

In the fourth phase, the reconciled version of the RSQ in Brazilian Portuguese was handed to a professional translator, native of the United States, and a foreign collaborator, both fluent in Portuguese and English, who conducted two independent back-translations into English. These back-translations were compared to the original RSQ (phase 5). Adjustments were made based on the comparisons. The project's coordinators judged that the stage of harmonizing the back-translations in different languages was not necessary since this was a process of translation into one specific language, and moved on to the seventh phase, in which the second version of the RSQ was applied to a sample of 20 healthy elderly individuals, contacted via the primary health network, only to verify possible problems with comprehension of the instrument during application.

After the satisfactory result of the pilot application, the coordinators submitted the applied version of the RSQ in Brazilian Portuguese for revision, applying appropriate orthographic corrections (phase 9), thus arriving at its final version, whose development process is here documented (phase 10).

To measure test-retest reliability, a sample of elders aged $\geq 60$ years, enrolled in the Cerebral Aging Program (Programa de Envelhecimento Cerebral [PENCE]) of a Family Health Strategy (Estratégia de Saúde da Família [ESF]) facility in the city of Porto Alegre, state of Rio Grande do Sul, southern Brazil, was selected. The PENCE is longitudinal cohort study that aims to examine factors associated with mental health in a sample of elderly with disadvantaged socioeconomic status in Brazil.

Subjects participating in both the pilot application and the test-retest measurement were recruited by general practitioners in family health facilities from different neighborhoods in the city of Porto Alegre and by health care workers in the PENCE program, and were evaluated at Hospital São Lucas, Porto Alegre, Brazil. All subjects provided written consent to their participation in the study, answered a socialdemographic questionnaire and were evaluated using Addenbrooke's Cognitive Examination - Revised Version (ACE-R) and the Mini International Neuropsychiatric
Interview (MINI) to exclude any possible cognitive impairments or psychiatric pathologies. The results of the ACE-R were evaluated according to years of education. ${ }^{16}$ Individuals were excluded from the sample if they presented: 1) cognitive impairment or dementia; 2) major psychiatric disorder or central nervous system disease; 3) alcohol or drug abuse or dependency; 4) serious physical illness that impaired their participation in the study. The demographic data of the studied population are presented in Table 1 . The mean age was $71.7 \pm 6.6$; participants were predominantly female and with low education level.

The interview version of the RSQ in Brazilian Portuguese was applied in person to a sample of 43 elders. The retest was applied via telephone 12 to 18 months after the first application and was responded by 29 elders.

\section{Results}

The sentences in the Likert scale were translated, respectively, as "nada a ver comigo," "tudo a ver comigo" and "mais ou menos a ver comigo." In relation to the statements, the translation process did not require many adaptations (Table 2). Only 6 of the 30 items required the replacement of words or expressions to maintain the conceptual and semantic equivalence of the instrument. The expression "romantic partner," present in items 11, 21 and 29, was translated as "companheiro(a)," a word whose use to denote a love partner, regardless of the formalization status of the relationship, is already established in Brazilian Portuguese. Meanwhile, the expression "others are reluctant" (item 25), whose literal translation is of difficult comprehension to the majority of the Brazilian population, was translated in the first version as "os outros tem resistência." However, after the back-translation it was observed that this first construction drifted from the sentence's original meaning, and therefore we opted to use the translation "os outros evitam" in the instrument's final version.

Adaptations were also needed for the verbal expression "to merge," present in items 4 and 18, since its literal translation is rarely used in reference to interpersonal relations in the Brazilian context. Therefore, in the first version the expression used was "entregar completamente," in item 4, which proved not to satisfy the equivalence criteria, being then replaced in the final version with "unir." Meanwhile, in question 18 , the translation considered most appropriate to the sentence's context was "relacionar profundamente."

No comprehension difficulties were observed in relation to the declarative statements during the pilot 
application of the instrument. However, self-application proved to be a less than adequate format for this specific demographic group, considering the reading difficulties presented by elders with lower levels of education and those with visual impairments, both common within this age group. Therefore, the decision was made to develop another version to be applied as a structured interview.

The structured interview version was developed, starting with instructions for the interviewer on how to fill out the answers. The interviewer is oriented to read each one of the items and ask the interviewee to answer each one with "yes," "no," or "more or less." If the answer is "more or less," the interviewer should mark 3 on the Likert scale. If the answer is "yes," the interviewer should ask the interviewee to further choose between "a lot" or "totally", and then mark 4 or 5 , respectively, according to the answer given. If the answer is "no," the interviewer must ask the interviewee to choose between "a little" or "nothing," and mark 2 or 1 , respectively.
The statements did not suffer any significant alterations in relation to the translation, the only change being to grammatical agreement, from first person singular in the original and self-applied versions to third person singular in the interview version, and each statement beginning with "O(A) $\operatorname{Sr}(a)$. é uma pessoa que..." ("You are a person that..."). The expectation is that this new version minimizes the difficulties encountered during the pilot application and proves to be more adequate for use in the elderly Brazilian population.

Considering the possibility of conducting studies with elders who already present some type of cognitive impairment that hinders their self-assessment, we suggest that the instrument should be applied to a third party related to the patient as well. To this purpose, a separate version of the RSQ, specifically designed for informants, was developed based on the self-applied version.

Just as in the interview version, only grammatical agreement was modified in order to refer to a third

Table 1 - Sociodemographic variables of participants of the pilot application and test-retest measurement of the Brazilian version of the Relationship Scales Questionnaire (RSQ)

\begin{tabular}{|c|c|c|c|}
\hline & n (\%) & Minimum score & Maximum score \\
\hline Age, mean $\pm S D$ & $71.8 \pm 6.6$ & 60 & 87 \\
\hline Years of education, mean \pm SD & $5.34 \pm 4.2$ & 0 & 14 \\
\hline \multicolumn{4}{|l|}{ Family income } \\
\hline Up to $1 \mathrm{MS}$ & 6 & 13.9 & \\
\hline More than 1 up to $3 \mathrm{MS}$ & 20 & 46.5 & \\
\hline More than 3 up to $4 \mathrm{MS}$ & 4 & 9.3 & \\
\hline N/A & 13 & 30.2 & \\
\hline \multicolumn{4}{|l|}{ Gender } \\
\hline Female & 29 & 67.4 & \\
\hline Male & 14 & 32.6 & \\
\hline \multicolumn{4}{|l|}{ Marital status } \\
\hline Single & 3 & 6.9 & \\
\hline Married & 19 & 44.1 & \\
\hline Widower & 13 & 30.2 & \\
\hline $\mathrm{N} / \mathrm{A}$ & 8 & 18.6 & \\
\hline \multicolumn{4}{|l|}{ Skin color/race } \\
\hline White & 23 & 53.4 & \\
\hline Black & 5 & 11.6 & \\
\hline Brown & 6 & 13.9 & \\
\hline Indian & 1 & 2.3 & \\
\hline $\mathrm{N} / \mathrm{A}$ & 8 & 18.6 & \\
\hline
\end{tabular}

Data expressed as $\mathrm{n}(\%)$, unless otherwise specified.

$\mathrm{MS}=$ minimum salary $(\sim \mathrm{R} \$ 788.00$ at the time of study $) ; \mathrm{N} / \mathrm{A}=$ not answered; $\mathrm{SD}=$ standard deviation. 
Table 2 - Original version, reconciliation, back-translations and final self-report version items of the Relationship Scales Questionnaire (RSQ) in Brazilian Portuguese

\begin{tabular}{|c|c|c|c|c|}
\hline Source version & Reconciliation & Back-translation 1 & Back-translation 2 & $\begin{array}{l}\text { Final self-report } \\
\text { version }\end{array}$ \\
\hline $\begin{array}{l}\text { 1. I find it difficult to } \\
\text { depend on other people. }\end{array}$ & $\begin{array}{l}\text { 1. Eu acho difícil } \\
\text { depender de outras } \\
\text { pessoas. }\end{array}$ & $\begin{array}{l}\text { 1. I find it difficult to } \\
\text { depend on others. }\end{array}$ & $\begin{array}{l}\text { 1. I think it is difficult to } \\
\text { depend on other people }\end{array}$ & $\begin{array}{l}\text { 1. Eu acho difícil } \\
\text { depender de outras } \\
\text { pessoas. }\end{array}$ \\
\hline $\begin{array}{l}\text { 2. It is very important to } \\
\text { me to feel independent. }\end{array}$ & $\begin{array}{l}\text { 2. É muito importante } \\
\text { pra mim me sentir } \\
\text { independente. }\end{array}$ & $\begin{array}{l}\text { 2. It is very important for } \\
\text { me to feel independent. }\end{array}$ & $\begin{array}{l}\text { 2. It is very important for } \\
\text { me to feel independent. }\end{array}$ & $\begin{array}{l}\text { 2. É muito importante } \\
\text { pra mim me sentir } \\
\text { independente. }\end{array}$ \\
\hline $\begin{array}{l}\text { 3. I find it easy to get } \\
\text { emotionally close to } \\
\text { others. }\end{array}$ & $\begin{array}{l}\text { 3. Eu acho fácil me } \\
\text { vincular emocionalmente } \\
\text { com os outros. }\end{array}$ & $\begin{array}{l}\text { 3. I find it easy to } \\
\text { develop an emotional } \\
\text { attachment to others. }\end{array}$ & $\begin{array}{l}\text { 3. I find it easy to } \\
\text { connect myself with } \\
\text { other people. }\end{array}$ & $\begin{array}{l}\text { 3. Eu acho fácil } \\
\text { me aproximar } \\
\text { emocionalmente dos } \\
\text { outros. }\end{array}$ \\
\hline $\begin{array}{l}\text { 4. I want to merge } \\
\text { completely with another } \\
\text { person. }\end{array}$ & $\begin{array}{l}\text { 4. Eu quero me entregar } \\
\text { completamente a outra } \\
\text { pessoa. }\end{array}$ & $\begin{array}{l}\text { 4. I want to give myself } \\
\text { completely to another } \\
\text { person. }\end{array}$ & $\begin{array}{l}\text { 4. I want to give myself } \\
\text { completely to another } \\
\text { person. }\end{array}$ & $\begin{array}{l}\text { 4. Eu quero me unir } \\
\text { completamente a outra } \\
\text { pessoa. }\end{array}$ \\
\hline $\begin{array}{l}5 . \text { I worry that I will be } \\
\text { hurt if I allows myself } \\
\text { to become too close to } \\
\text { others. }\end{array}$ & $\begin{array}{l}\text { 5. Tenho medo de me } \\
\text { machucar/magoar } \\
\text { se eu me permito ter } \\
\text { relacionamentos muito } \\
\text { próximos com outras }\end{array}$ & $\begin{array}{l}\text { 5. I am scared of being } \\
\text { emotionally hurt if I allow } \\
\text { myself to have close } \\
\text { relations with others. }\end{array}$ & $\begin{array}{l}\text { 5. I'm afraid of hurting } \\
\text { myself if I have close } \\
\text { relationships with other } \\
\text { people. }\end{array}$ & $\begin{array}{l}\text { 5. Eu tenho receio de me } \\
\text { machucar/magoar se eu } \\
\text { me aproximar muito das } \\
\text { outras pessoas. }\end{array}$ \\
\hline
\end{tabular}

6. I am comfortable without close emotional relationship.

7. I am not sure that I can always depend on others to be there when I com os outros quando eu need them.

\section{I want to be} completely emotionally intimate with others.

9. I worry about being alone.

10. I am comfortable depending on other people.

11. I often worry that romantic partners don't really love me.

12. I find it difficult to trust others completely.

13. I worry about others getting too close to me.

14. I want emotionally close relationships.

15. I am comfortable having other people depend on me.

6. Eu me sinto bem sem ter relações emocionais próximas. precisar.

8. Quero ter muita intimidade com os outros.

9. Tenho medo de estar sozinho.

10. Fico confortável se preciso depender de outras pessoas.

11. Frequentemente tenho medo que meu companheiro não me ame realmente.

12. Acho difícil confiar completamente em

13. Me preocupo quando outras pessoas estão se tornando muito íntimas de mim. relações emocionais sejam íntimas. proximos com outras pessoas.

7. Não tenho certeza que 7. I am not sure I can always count on others outras pessoas.

6. I feel good without having emotionally close relationships. having emotional close

8. I want to have lots of intimacy with others.

9. I am afraid of being alone.

10. I feel comfortable depending on others.

11. I am frequently afraid that my partner does not really love me.

\section{I find it difficult to} trust others completely.

13. I get worried when other people are becoming too intimate with me.

13. I worry myself

14. Quero que as minhas 14. I want my emotional relationships to be intimate. $\begin{array}{ll}\text { 15. Me sinto confortável } & 15 \text {. I feel comfortable } \\ \text { tendo outras pessoas que having others depend }\end{array}$ dependam de mim. on me.
6. I feel well without relationships.

7. I'm not sure if I always can count on others when I need.

8. I want to have much intimacy with the others.

9. I'm afraid of being alone.

10. I'm comfortable if I need to depend on other people.

\section{I am frequently afraid that my mate doesn't really love me.}

12. I find it difficult to trust completely in othe people. when other people are becoming too close to me.

14. I want my emotional relationships to be intimate.

6. Eu me sinto à vontade sem ter relações emocionais próximas.

7. Eu não estou certo(a) que posso contar sempre com os outros quando eu precisar.

8. Quero ter uma intimidade emocional plena com os outros.

9. Tenho receio de estar sozinho(a).

10. Fico confortável se preciso depender de outras pessoas.

11. Muitas vezes tenho receio que meu companheiro(a) não me ame realmente.

12. Acho difícil confiar completamente em outras pessoas.

13. Me preocupo quando outras pessoas estão se tornando muito próximas de mim.

14. Quero relacionamentos emocionalmente mais próximos.

15. I feel comfortable having other people who depend on me.
15. Me sinto confortável tendo outras pessoas que dependam de mim. 


\begin{tabular}{l} 
Source version \\
\hline 16. I worry that others \\
don't value me as m \\
as I value them. \\
17. People are never \\
there when you need
\end{tabular}

them.

18. My desire to merge completely sometimes scares people away.

19. It is very important to me to feel selfsufficient.

20. I am nervous when anyone gets too close to me.

21. I often worry that romantic partners won't want to stay with me.

22. I prefer not to have other people depend on me.

23. I worry about being abandoned.

24. I am somewhat uncomfortable being close to others.

25. I find that others are reluctant to get as close as I would like.

26. I prefer not to depend on others.

27. I know that others will be there when I need them.

28. I worry about having others not accept me.

29. Romantic partners often want me to be closer than I feel comfortable being.

30. I find it relatively easy to get close to others.

\section{Reconciliation}

16. Me preocupo se os outros não me valorizam tanto quanto eu valorizo eles.

17. Penso que as pessoas 17. I think people are nunca estão lá quando se never there for me when precisa delas.

I need them.

18. Minha vontade de me 18. My desire for deep relacionar profundamente relationships sometimes às vezes afasta as drives people away. pessoas.

19. É muito importante pra mim me sentir independente.

20. Fico incomodado quando alguém se torna muito íntimo de mim.

21. Frequentemente me preocupo que meu companheiro não queira ficar comigo.

22. Prefiro não ter outras 22. I prefer not to have pessoas que dependam others depend on me. de mim.

23. Tenho medo de ser abandonado.

24. Fico um pouco desconfortável em ficar muito íntimo de outras pessoas.

25. Acho que os outros têm resistência em se aproximarem de mim o quanto eu gostaria.

26. Prefiro não depender dos outros.

27. Sei que os outros vão estar disponíveis quando precisar deles.

28. Eu me preocupo que outras pessoas não me aceitem.

29. Meu companheiro frequentemente quer que eu seja mais próxima do que eu me sinto confortável em ser.

30. Acho relativamente fácil ter relacionamentos próximos com outras pessoas. wants me to be closer
19. It is very important to me to feel independent.

20. I feel uncomfortable when someone becomes too intimate with me.

21. I frequently worry that my partner does not that my mate doesn't want to be with me. want to stay with me.

22. I prefer not having other people depending on me.

23. I am afraid of being abandoned.

\section{I'm afraid of being} abandoned.

\section{I get a bit}

24. I feel a little uncomfortable about become too intimate with becoming too close to others. other people.

25. I think other people are resistant to approach me as much as I would like.

25. I think the others are adamant about approaching me how much I would.

26. I prefer not to depend on others.

27. I know others will be available when I need them.

28. I worry that other people don't accept me

29. My partner often than I feel comfortable being.

30. I find it relatively easy to have close relations with others.
26. I prefer not to depend on others.

27. I know that the other people will be available when I need them.

28. I worry that other 28. Eu me preocupo que outras pessoas não me aceitem.

29. My mate frequently wants me to be closer than I feel comfortable to be.

30. I think it is easy to have close relationships with other people.

26. Eu prefiro não depender dos outros. estar disponíveis quando precisar deles.

29. Muitas vezes meu(minha) eu seja mais próximo(a) do que eu me sinto confortável em ser.

30. Acho relativamente fácil me aproximar das outras pessoas.
Final self-report

version

16. Me preocupo se os
outros não me valorizam tanto quanto eu valorizo eles.

17. Penso que as pessoas nunca estão lá quando se precisa delas.

18. Minha vontade de me relacionar profundamente às vezes afasta as pessoas.

19. É muito importante pra mim me sentir autossuficiente.

20. Fico nervoso(a) quando alguém se torna muito íntimo de mim.

21. Muitas vezes tenho receio que meu(minha) companheiro(a) não queira ficar comigo.

22. Prefiro não ter outras pessoas que dependam de mim.

23. Eu tenho receio de ser abandonado(a).

24. Fico um pouco desconfortável sendo muito próximo(a) de outras pessoas.

25. Eu acho que os outros evitam se aproximar de mim quanto eu gostaria.

27. Sei que os outros vão companheiro(a) quer que 
Table 3 - Test-retest evaluation of the interview version of the Relationship Scales Questionnaire (RSQ) in Brazilian Portuguese

\begin{tabular}{lccc}
\hline & \multicolumn{1}{c}{ Test } & Retest & \\
\cline { 2 - 3 } & Mean \pm SD & Mean \pm SD & P \\
\hline Secure & $3.12 \pm 0.66$ & $3.54 \pm 0.85$ & 0.011 \\
Fearful & $3.03 \pm 0.74$ & $2.93 \pm 0.79$ & 0.525 \\
Dismissing & $3.74 \pm 0.54$ & $3.88 \pm 0.82$ & 0.343 \\
Preoccupied & $2.75 \pm 0.66$ & $2.71 \pm 0.90$ & 0.800 \\
\hline
\end{tabular}

$\mathrm{SD}=$ standard deviation

Mean scores; $\min -\max =1-5$.

person, with each statement beginning with " $O(A) \operatorname{Sr}(a)$. [NOME] é uma pessoa que..." ("Mr. or Ms. [NAME] is a person that..."), in which the interviewer must say the name of the person about whom they wish to gather information. The instructions for the interviewer remain the same as in the interview version. In both versions, the interview and the informant versions, the statements should be read exactly as they are written in order to minimize any biases caused by differences between written and spoken languages.

In order to assess test-retest reliability, statistical analyses were conducted using the Statistical Package for the Social Sciences (SPSS) version 21.0, adopting a significance level of $5 \%(p<0.05)$. Quantitative variables were described as mean and standard deviation, with the scores being calculated using the Griffin \& Bartholomew model for types of attachment ${ }^{10}$ and compared using the paired sample $t$-test (Table 3 ).

Although the measure for secure attachment showed differences in the answers between the first and second applications, the other measures of attachment did not present differences, suggesting reliability of the final version of the instrument. We highlight some limitations of this study, such as the small sample size and the long interval between the applications. Another aspect that should be emphasized in studies on levels of attachment in elderly individuals is that, although there is a tendency for styles of attachment to remain stable throughout one's life, the occurrence of significant life events and environmental changes may lead to modifications.

\section{Conclusion}

The Brazilian adaptation of the RSQ is the first step in the development of a standardized attachment evaluation instrument for individuals over 60 years of age. We highlight that the RSQ is designed as a research instrument and is not intended for clinical or diagnostic purposes. All questionnaires are available online as supplementary material. Thus, competent professionals can now use this tool in Brazilian Portuguese for the purposes of scientific research.

\section{Acknowledgements}

Eunice Neves de Assis and Fernanda Loureiro received financial support from Coordenação de Aperfeiçoamento de Pessoal de Nível Superior (CAPES). This institution was not involved in any stage of study design, data collection or manuscript drafting, and had no association with the study itself save for the financial support provided to the authors mentioned.

The authors are grateful to all participants.

\section{Disclosure}

No conflicts of interest declared concerning the publication of this article.

\section{References}

1. Organização das Nações Unidas. Plano de ação internacional sobre o envelhecimento, 2002. Brasília: Secretaria Especial dos Direitos Humanos; 2003.

2. Brasil. Plano de ações estratégicas para o enfrentamento das doenças crônicas não transmissíveis (DCTN) no Brasil 2011/2022. Brasília: Ministério da Saúde; 2011.

3. Pimenta FAP, Bicalho MAC, Romano-Silva MA, Moraes EN, Rezende NA. Doenças crônicas, cognição, declínio funcional e Índice de Charlson em idosos com demência. Rev Assoc Med Bras. 2013;59:326-34.

4. Bowlby J. Apego: a natureza do vínculo. 2th ed. São Paulo: Martins Fontes; 1969.

5. Abreu CN. Teoria do apego: fundamentos, pesquisas e implicações clínicas. São Paulo: Casa do Psicólogo; 2005.

6. Tracy RL, Ainsworth MD. Maternal affectionate behavior and infant-mother attachment patterns. Child Dev. 1981;52:1341-3.

7. Hazan C, Shaver PR. Love and work: An attachment-theoretical perspective. J Pers Soc Psychol. 1990;59:270-80.

8. Bartholomew K. Avoidance of intimacy: an attachment perspective. J Soc Pers Relat. 1990;7:147-78.

9. Bartholomew K, Horowitz LM. Attachment styles among young adults: A test of a four-category model. J Pers Soc Psychol. 1991;61:226-44.

10. Griffin D, Bartholomew K. Models of the self and other: fundamental dimensions underlying measures of adult attachment. J Pers Soc Psychol. 1994;67:430-45.

11. Miesen BML. Alzheimer's disease, the phenomenon of parent fixation and Bowlby's attachment theory. Int J Geriatr Psychiatry. 1993; 8:147-53.

12. Browne CJ, Shlosberg E. Attachment behaviors and parent fixation in people with dementia: The role of cognitive functioning and pre-morbid attachment style. Aging Ment Health. 2005;9:15361.

13. Magai C, Cohen CI. Attachment style and emotion regulation in dementia patients and their relation to caregiver burden. J Gerontol B Psychol Sci Soc Sci. 1998;53:147-54.

14. Ng QX, Ho CYX, Koh SSH, Tan WC, Chan HW. Doll therapy for dementia sufferers: A systematic review. Complement Ther Clin Pract. 2017;26:42-6. 
15. Wild D, Grove A, Martin M, Eremenco S, McElroy S, VerjeeLorenz $\mathrm{A}$, et al. Principles of good practice for the translation and cultural adaptation process for patient-reported outcomes (PRO) measures: report of the ISPOR Task Force for Translation and Cultural Adaptation. Value Health. 2005;8:94-104.

16. César KG, Yassuda MS, Porto FHG, Brucki SMD, Nitrini, R. Addenbrooke's cognitive examination-revised: normative and accuracy data for seniors with heterogeneous educational level in Brazil. Int Psychogeriatr. 2017;29:1345-53.

\section{Correspondence:}

Eunice Neves de Assis

Hospital São Lucas

Av. Ipiranga $6690,3^{\circ}$ andar, sala 321, Jardim Botânico

90620-000 - Porto Alegre, RS - Brazil

Tel.: + 55 (51) 981955339

E-mail: eunicedeassis@yahoo.com.br 